\title{
Additions To The Moss Flora of Endau Rompin National Park, Johore State, Peninsular Malaysia
}

\author{
Boon Chuan Ho and Benito C. Tan \\ Department of Biological Sciences, National University of Singapore, 10 Kent Ridge \\ Crescent, Singapore 119260
}

\begin{abstract}
In a recent survey of the Endau Rompin National Park (ERNP) in Johore State, 81 species and 4 varieties of mosses were documented. This increases the previous count from 62 species and 3 varieties of mosses in ERNP to 111 species and 5 varieties in total. Of these, 30 species are new records for Johore State. Rhaphidostichum bunodicarpum and Trichosteleum stigmosum are two species new to Peninsular Malaysia. Thuidium assimile is a new record for West Malesia. A new combination, Papillidiopsis aquaticum (Dix.) Boon-Chuan Ho \& B.C. Tan is proposed. In terms of species composition, the pan-tropical families of Calymperaceae, Fissidentaceae, Leucobryaceae and Sematophyllaceae predominate the moss flora of ERNP.
\end{abstract}

\section{INTRODUCTION}

Few publications have reported exclusively on the mosses of Peninsular Malaysia and Johore state. Noteworthy literature includes a long list of mosses reported from the Malay Peninsular by Dixon (1926) and a more recent updated checklist of mosses, 62 years later, by Mohamed and Tan (1988). For the state of Johore alone, Mohamed and Tan (1988) reported 97 species in 44 genera and 18 families. The only comprehensive moss flora for Johore and the Ulu Endau was by Mohamed and Mohamad (1987) who participated in the first biodiversity survey of Endau Rompin area in 1985.
Gazetted in 1993, Endau Rompin (ERNP, see Map 1) was the second area in Peninsula Malaysia (after Taman Negara) to be designated as a National Park. It consists of an extensive area of 49,000 hectares of pristine tropical lowland mixed dipterocarp forest that straddles the border between the Johore and Pahang states, and harbours a large number of rare and endemic plant species (Kiew et al., 1987). As the area is also the watershed of the rivers Endau in Johore and Rompin in Pahang, its protection is important for the conservation of plant diversity and also for the economic development of the lower Peninsular Malaya. 
The first report of mosses of Endau Rompin National Park listed 62 species and 3 varieties in 34 genera and 16 families (Mohamed and Mohamad, 1987). Considering the vast area of this National Park the local moss flora appears to be low in diversity and number of species. The Bukit Timah Nature Reserve in Singapore, with about 164 hectares of disturbed primary lowland rainforest, has 71 moss species in 28 genera and 16 families (unpublished data, 2002).

\section{MATERIALS AND METHODS}

The main objective of the present study is to conduct a new survey of the moss flora in ERNP and to increase the knowledge of the moss diversity in this National Park. In August and October of 2001 two short visits, totalling five days, were made to the Johore side of ERNP in order to investigate the moss flora. Collections were made mainly around the Nature Education and Research Centre (NERC) and along the following chosen trails and sites (see Map 1) -

Pacat trail \& West trail 3 - 24 August 2001.

Nature Education and Research Centre (NERC) \& main road to its entrance 25 August 2001, 26-27 October 2001.

Trail from Kuala Jasin to Kuala Marong to Tasik Air Biru to Upeh Guling — 25 August 2001.

Trail from Kuala Jasin to Janing Barat Plateau - 26 August 2001.

4a. At Kuala Jasin - 26 August 2001.

Kampong Peta - 27 October 2001.

Sungei Semawak (near NERC) - 27 October 2001.

East Trail $2 \& 3-27$ October 2001.

Stream near East Trail 4 — 27 October 2001.

Voucher specimens of various mosses encountered during the field survey were made from all habitats along the trails and occasionally off the trails. Details of location, substrate, illumination and abundance of plants were recorded for each collection. Materials were subsequently identified using the latest monographs and revisions, properly labelled and packeted, and deposited in the Herbarium (SINU) of Raffles Museum of Biodiversity Research, The
National University of Singapore. Duplicates were sent to the Nature Education and Research Centre (NERC) and selected overseas herbaria for record keeping.

\section{RESULTS AND DISCUSSION}

Appendix 1 lists the mosses of ERNP obtained from the present survey. Each species is accompanied with information of the collection localities, habitat, abundancy of plants and the specimens studied. Species reported earlier in Mohamed and Mohamad (1987) but not seen in this study are listed in Appendix 2 for reference.

The new field work in ERNP has yielded a total of 81 species and 4 varieties of mosses in 38 genera and 15 families. Of these, 49 species and 2 varieties are new records for ERNP. This represents a $79 \%$ increase on the 62 species and 3 varieties previously reported by Mohamed and Mohamad (1987), bringing the total number of mosses known in ERNP to 111 species and 5 varieties in 47 genera and 18 families. These additions make the moss flora of Endau Rompin the best known in the state of Johore, Peninsular Malaysia.

Of the 49 new moss records in ERNP, more than one third belongs to the family Sematophyllaceae (18 species). With 13 genera, the Sematophyllaceae is the dominant family at the generic level. The significant increase in the recorded taxa in this family, from the previously reported nine species to 27 , is probably due to oversight by previous collectors, or lack of familiarity in recognizing the taxa of this taxonomically difficult family in the field (Tan and Jia, 1999). Other large families of mosses found in ERNP are the Calymperaceae, Fissidentaceae and Leucobryaceae (see Appendices 1 \& 2).

Map 1: Part of Endau-Rompin National Park showing the locations surveyed (modified from Map of Trail for Education Module provided by NERC). 


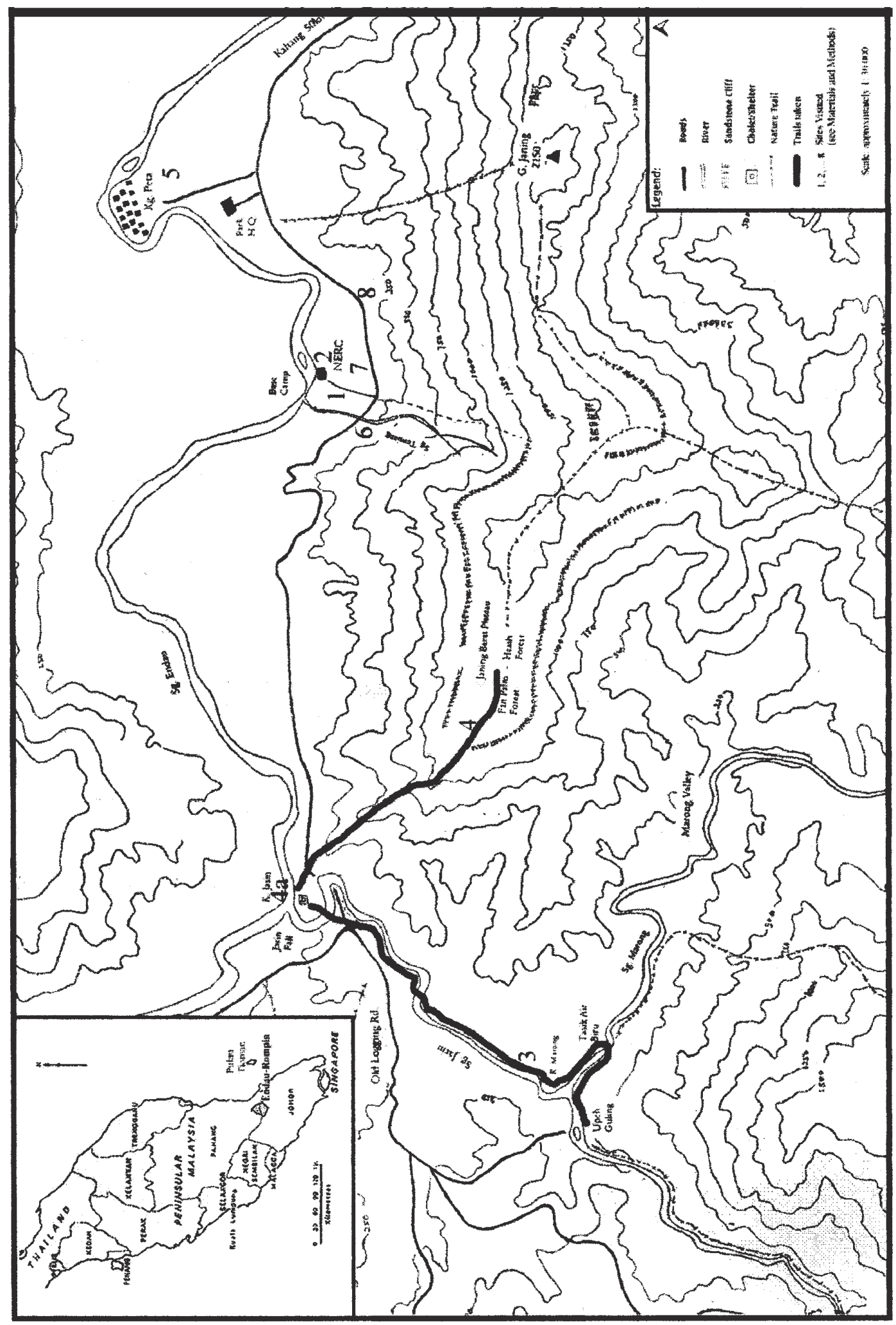

TROPICAL BRYOLOGY 22 (2002) 
Interestingly, Tan and Mohamed (1999) had recently provided a checklist of 89 species of mosses in 49 genera for Pulau Tioman, a small island with an area of 13,360 ha off the eastern coast of Peninsular Malaysia. Although Pulau Tioman is politically part of the state of Pahang, it is geographically nearer to the state of Johore. Indeed, the majority of the mosses of Pulau Tioman are also found in ERNP. Examples are Acroporium lamprophyllum, Arthrocormus schimperi, Diphyscium mucronifolium, Fissidens crassinervis, F. ceylonensis, Isocladiella surcularis, Himantocladium cyclophyllum, Leucobryum arfakianum, Leucoloma molle, Mitthyridium repens, M. flavum, Papillidiopsis ramulina, Radulina hamata, Syrrhopodon albovaginatus, $S$. croceus, Thuidium glaucinoides and Trismegistia rigida. Together the two floras represent the characteristic mosses of lowland dipterocarp forest in Peninsular Malaya.

Of the taxa newly reported for ERNP, 30 species are new additions to the known moss flora for the state of Johore (refer to appendix 1). Furthermore, three species, Thuidium assimile, Rhaphidostichum bunodicarpum and Trichosteleum stigmosum are new to Peninsular Malaysia and Singapore. In fact, the collection of Thuidium assimile represents a significant new record for West Malesia. Being widespread in the temperate and boreal parts of Northern Hemisphere, T. assimile is distributed in Asia from India, Nepal, Bhutan, China and New Guinea (Touw, 2001), in addition to Peninsular Malaya. Rhaphidostichum bunodicarpum was reported from China (Hainan), Borneo, Philippines, Indonesia, Papua New Guinea and a few island groups in Oceania (Tan and Jia, 1999). Our collection from Peninsular Malaya represents a new locality for this species. Finally, Tan (1993) stated that Trichosteleum stigmosum, a species known from China, Philippines, Papua New Guinea, Samoa and Fiji (Tan and Jia, 1999), was unduly considered by Dixon (1926) as a synonym of Acanthorrhynchium papillatum (Harv.) Fleisch. Consequently, as a taxonomic synonym, T. stigmosum has been forgotten for more than half a century (Tan, 1993). The record from Peninsular Malaysia is a good extension of its confirmed range of distribution.
Equally important are the large number of uncommon and rare Malesian mosses found in ERNP. They are Cladopodanthus heterophyllus, Clastobryum cuculligerum, Ephemeropsis tjibodensis, Leucoloma amoenevirens, Mastopoma scabrifolium, Oedicladium pseudorufescens, Papillidiopsis bruchii, P. malayana, Radulina elegantissima, Sematophyllum microcladioides and Splachnobryum oorschoii. Mastopoma scabrifolium has a narrow range, being restricted to Thailand (Khao Yai National Park), Peninsular Malaya, with an outlier locality in Java (Tan and Tran Ninh, 1998).

Having such a diverse moss flora, the ERNP is indeed worth conserving, especially along the trail from Kuala Jasin to Upeh Guling via Kuala Marong and Tasik Air Biru. The other area of interest is the Janing Barat Plateau. The moss diversity in these places is both high and unique. Since all the past and present collections have concentrated along the available trails inside the park boundary and near sea level, future effort should focus on the high elevations and stay away from the well-established trails. Future surveys should also include the Pahang side of the National Park. Considering that lowland rain forests in Peninsular Malaysia are fast being replaced by agricultural plantations and human settlements, the completion of the moss flora of this National Park has become an urgent undertaking, not only to complete the inventory of the moss diversity of Peninsular Malaysia, but also to produce new information for a better understanding of the bryogeography of the Western Malesian region.

\section{ACKNOWLEDGEMENTS}

We are grateful to the NERC for allowing us to conduct the moss survey in the ERNP. We would like to thank the staff of NERC for their assistance and hospitality during our stay in the ERNP. The field assistance of Farida binti Yusuf, Chang Ying, Chia Su-Fern is appreciated. Financial support for field work was also provided by NUS Research Grant (R-154-000-084112) awarded to the second author. We also thank Mr. A.A. Leonardia for letting us report his moss 
collections from ERNP. The reviews of Drs. H. Higuchi and L.T. Ellis are most helpful.

\section{REFERENCES}

Dixon, H.N. 1926. A list of the mosses of the Malay Peninsula. The Gardens'Bulletin, Straits Settlements 4: 1-46.

Kiew, B.H., G.W.H. Davison and R. Kiew. 1987. The Malaysian heritage and scientific expedition: Endau-Rompin, 1985-1986. Malayan Nature Journal 41: 83-92.

Mohamed, H and A.D. Mohamad. 1987. The moss flora of Ulu Endau, Johore, Malaysia. Malayan Nature Journal 41: 183-189.

Mohamed, H. and B.C. Tan 1988. A checklist of mosses of Peninsular Malaya and Singapore. The Bryologist 91: 24-44.

Tan, B.C. 1991. Miscellaneous notes on Asiatic mosses, especially Malesian Sematophyllaceae (Musci) and others. Journal of Hattori Botanical Laboratory 70: 91-106.

Tan, B.C. 1993. Noteworthy range extension of Malesian mosses. Journal of Hattori Botanical Laboratory 74: 227-233.

Tan, B.C. and Y. Jia. 1999. A preliminary revision of Chinese Sematophyllaceae. Journal of Hattori Botanical Laboratory 86: 1-70.

Tan, B.C. and H. Mohamed. 1999. A preliminary checklist of mosses of Pulau Tioman, Peninsular Malaysia. The Raffles Bulletin of Zoology, Supplement 6: 73-76.

Tan, B.C. and Tran Ninh. 1998. New records for Thailand and Vietnam moss floras. Acta Botanica Yunnannica 20: 271-275.

Touw, A. 2001. A taxonomic revision of the Thuidiaceae (Musci) of Tropical Asia, the Western Pacific, and Hawaii. Journal of Hattori Botanical Laboratory 91: 1-136.

Appendix 1. List of mosses of Endau Rompin National Park collected in this study (for locality number information, see text). The comments on habitat, substrates, frequency of distribution and abundance of species are based on field observation made during the recent survey. An asterisk (*) indicates taxa new to Endau Rompin National Park, $(* *)$ indicates taxa new to Johore, and $(* * *)$ indicates taxa new to Peninsular Malaysia.

TROPICAL BRYOLOGY 22 (2002)
Acanthorrynchium papillatum (Harv.) Fleisch. Locations 3, 6 \& 7; lignicolous, corticolous, rupicolous, terricolous, semishaded to shaded, common and relatively abundant. Specimens examined: Tan 2001-05; Ho 01-088, 01-092, 01-105, 01$109,01-119,01-121,01-122,01-126,01-$ 128, 01-283, 01-284.

**Acroporium johannis-winkleri Broth. Location 3; lignicolous, shaded, locally uncommon. Specimen examined: Ho 01077.

**Acroporium lamprophyllum Mitt. - Locations 3 \& 6; corticolous, shaded, uncommon. Specimens examined: Ho 01-131, 01-285.

** Acroporium microcladum (Fleisch.) B.C. Tan [syn. Sematophyllum microcladiellum Fleisch.] -Location $2 \& 3$; rupicolous, corticolous, open site, rare. Specimens examined: Ho 01-078, 01-292.

Acroporium strepsiphyllum (Mont.) B.C. Tan [syn. A. falcifolium Fleisch.] -Locations 3 \& 4; corticolous, on exposed tree roots, open, uncommon. Specimens examined: Tan 2001-32; Ho 01-076.

Arthrocormus schimperi Dozy \& Molk. Locations 1 \& 3; corticolous, semi-shaded to shaded, common and locally abundant. Specimens examined: Ho 01-063, 01-116, 01-118.

**Bryum apiculatum Schwaegr. -Location 2; terricolous, open, preferred wet sites, locally abundant. Specimen examined: $\mathrm{Ho}$ 01-257.

* Callicostella papillata (Mont.) Mitt. var. papillata -Location 1; rupicolous, shaded, common in wet sites. Specimen examined: Ho 01-090.

Callicostella papillata var. prabaktiana (C. Muell.) Streim. [syn. Schizomitrum prabaktianum (C. Muell.) Miller et al.] Location 6; rupicolous, near stream, shaded, uncommon. Specimens examined: Ho 01-235, 01-241.

* Calymperes afzelii Sw. -Location 2; corticolous, semi-shaded, uncommon. Specimen examined: Ho 01-042.

* Calymperes erosum C. Muell. -Locations 2 $\& 3$; corticolous, rupicolous, open to semishaded, uncommon, locally forming large 
patch. Specimens examined: Ho 01-038, 01-255.

* Calymperes fasciculatum Dozy \& Molk. Location 3; corticolous, shaded, forming small population. Specimen examined: Ho 01-041.

* Calymperes graeffeanum C. Muell. Locations 3 \& 4; often rupicolous, also corticolous, in shade, forming large populations. Specimens examined: Tan 2001-22, 2001-27; Ho 01-039.

Calymperes lonchophyllum Schwaegr. Locations 1, 3, 6 \& 7; often corticolous, also on tree base, rupicolous, shaded to deeply shaded, forming large patches on wet boulders. Specimens examined: $\mathrm{Ho}$ 01-046, 0-050, 01-232, 01-238, 01-242, 01-251.

* Calymperes serratum A. Br. ex C. Muell. Location 1 \& 3; corticolous, shaded, uncommon. Specimens examined: Ho 01043, 01-051.

**Cladopodanthus heterophyllus (Fleisch.) Bartr. - Location 3; found littered on forest floor, growing on high branches in canopy. Specimens examined: Ho 01089; Tan 2001-01.

**Clastobryum cuculligerum (Lac.) Tix. Location 8; on fallen tree branch, open site, uncommon, forming small population. Specimen examined: Ho 01287.

Diphyscium mucronifolium Mitt. [syn. D. involutum Mitt.] - Trail to Gng Janing from Visitor's Centre, on rock, $560 \mathrm{~m}, A A$ Leonardia B02-1280.

*Distichophyllum nigricaule Mitt. ex Bosch \& Lac. var.cirratum (Ren. \& Card.) Fleisch. - Trail to Gng Janing from Visitor's Centre, on rock, $595 \mathrm{~m}$, AA Leonardia B02-1220.

**Ectropothecium dealbatum (Reinw. \& Hornsch.) Jaeg. - Location 2; rupicolous, open area, forming small population. Specimen examined: Ho 01-275.

Ectropothecium eleganti-pinnatum (C. Muell.) Jaeg. - Locations 6 \& 7; rupicolous, semishaded to shaded, common, abundant. Specimens examined:Ho 01-240, 01-276, 01-277, 01-278.
* Exostratum blumii (Nees ex Hampe) Ellis [syn. Exodictyon blumii (Nees ex Hampe) Fleisch.] -Location 1; corticolous, deeply shaded, locally sparse. Specimen examined: Ho 01-062.

Fissidens crassinervis Lac. - Location 4; usually terricolous, shaded, common inside forest. Specimens examined: Ho 01-032, 01-034.

Fissidens crispulus Brid. [syn. F. zippelianus Dozy \& Molk.] —Location 6; rupicolous, near stream, shaded, forming small population. Specimens examined: Ho 01 233, 01-239.

** Fissidens guangdongensis Iwats. \& Z.-H. Li -Location 4; terricolous, shaded, uncommon. Specimen examined: $\mathrm{Ho} 01$ 033.

** Fissidens pallidus Hook. \& Wils. - Location 3 ; terricolous, shaded, forming small populations. Specimens examined: Tan 2001-16; Ho 01-030, 01-037.

Fissidens pellucidus Hornsch. [syn.F. laxus Sull. \& Lesq.] - Locations 2 \& 3; terricolous, open to shaded sites, common in the forest. Specimens examined:Ho 01-029, 01-031.

*Floribundaria floribunda (Dozy \& Molk.) Fleisch. -Location 1; ramicolous, hanging from branches, shaded. Specimen examined: Tan 2001-18.

*Himantocladium cyclophyllum (C. Muell.) Fleisch. - Locations 1 \& 6; corticolous, rupicolous, near stream, shaded to deeply shaded, frequently encountered. Specimens examined:Ho 01-096, 01-262.

Homaliodendron exiguum (Bosch \& Lac.) Fleisch. -Location 1; corticolous, deeply shaded, uncommon. Specimen examined: Ho 01-097.

Isocladiella surcularis (Dix.) B.C. Tan \& Mohamed -Locations 3 \& 4; usually ramicolous, twining around small branches and twigs, also corticolous and epiphyllous, inside forest, shaded, locally in small population. Specimens examined: Tan 2001-10; Ho 01-085, 01-086.

*Isopterygium albescens (Hook.) Jaeg. Location 2; terricolous, corticolous, on tree base, open site, locally in small patches. Specimens examined: Ho 01 - 
256, 01-274.

** Isopterygium bancanum (Lac.) Jaeg. Locations $1 \&$ 7; rupicolous, corticolous, on exposed roots; deeply shaded, forming mat. Specimens examined: Ho 01-094, 01-280.

*Leucobryum aduncum Dozy \& Molk. Locations 3 \& 4; often lignicolous, sometimes corticolous on tree base, seldom rupicolous, semi-shaded to shaded, locally forming cushion. Specimens examined: Ho 01-072, 01-073, 01-074, 01-112.

** Leucobryum arfakianum C. Muell. ex Geh. [syn. L. subsanctum Broth.] -Locations $3 \& 4$; corticolous on exposed roots or tree base, semi-shaded to shaded, not common. Specimens examined: Ho 01-069, 01-071.

Leucobryum bowringii Mitt. -Location 4; corticolous; semi-shaded to shaded, locally forming cushion. Specimens examined: Tan 2001-11; Ho 01-067, 01070.

** Leucobryum chlorophyllosum C. Muell. Locations 3 \& 4; rupicolous, corticolous on exposed roots; semi-shaded, forming small mat. Specimens examined: Ho 01075, 01-103.

* Leucobryum javense (Brid. ex Schwaegr.) Mitt. -Location 4; terricolous, semi-shaded, uncommon. Specimen examined: Ho 01066.

Leucobryum sanctum (Brid.) Hampe - Locations 3 \& 6; lignicolous, corticolous, semishaded to shaded, can be locally abundant. Specimens examined: Ho 01-068, 01-120, 01-123, 01-245.

*Leucoloma amoene-virens Mitt. _Locations 3 \& 6; rupicolous, semi- to full shaded, form large patches locally. Specimens examined: Ho 01-040, 01-258.

Leucophanes albescens C. Muell. - Location 1; corticolous, semi-shaded, common, forming large cushion. Specimen examined: Ho 01-065.

Leucophanes octoblepharioides Brid. Locations 1 \& 7; corticolous, lignicolous, shaded, common. Specimens examined: Ho 01-064, 01-253.

**Mastopoma scabrifolium (Broth.) B.C. Tan \&
Tran Ninh [syn. Acanthocladium scabrifolium Broth.] -Location 4; corticolous, on root stump, shaded, forming thick mat. Specimen examined: Tan 2001-12.

This species seems common in the southern tip of Peninsular Malaysia with newly discovered localities in Gunung Panti and ERNP, both in Johore State. The plants combine the appearance of Wijkia and Trismegistia. They resemble species of the former in having a highly pinnatifid branching system with differentiated stem and branch leaves, and species of the latter in having penicillate branch tips and somewhat differentiated leaf borders. Tan and Tran Ninh (1998) provide the justification for the inclusion of this species in Mastopoma.

* Meiothecium microcarpum (Hook.) Mitt. Locations 2 \& 5; ramicolous, lignicolous; open to semi-shaded, common in disturbed sites. Specimens examined: $\mathrm{Ho}$ 01-289, 01-290.

**Microdus brasiliensis (Duby) Thér. Location 2; terricolous; open, weedy but seasonal. Specimen examined: Ho 01 259.

*Mitthyridium constrictum (Sull.) Robins. Location 2; corticolous, open, forming small patches. Specimens examined: $\mathrm{Ho}$ 01-266, 01-267.

Mitthyridium crassum (Broth.) Robins. Location 3; corticolous on fallen tree trunk, shaded, uncommon. Specimen examined: Tan 2001-15.

Mitthyridium fasciculatum (Hook. \& Grev.) Robins. -Locations 6 \& 8; corticolous, somewhat open site, common, small populations. Specimens examined: $\mathrm{Ho}$ 01-264, 01-268.

** Mitthyridium flavum (C. Muell.) Robins. Location 2; corticolous on tree base, at times ramicolous, open site, not common. Specimens examined: Ho 01-058, 01-270.

Mitthyridium jungquilianum (Mitt.) Robins. Locations 2 \& 3; corticolous, on fallen tree, open to shaded sites, small populations. Specimens examined: Tan 2001-24; Ho 01-059, 01-265. 
** Mitthyridium luteum (Mitt.) Robins. Location 1; ramicolous, deeply shaded, scattered populations. Specimen examined: Ho 01-060.

Mitthyridium repens (Harv. in Hook.) Robins. Location 2; ramicolous, common in open and disturbed forest. Specimen examined: Ho 01-269.

Mitthyridium undulatum (Dozy \& Molk.) Robins. -Location 1; ramicolous, lignicolous, semi-shaded to shaded, frequently forming cushions. Specimens examined: Ho 01057, 01-061.

Oedicladium pseudorufescens (Hampe) B.C. Tan \& Mohamed [sy Myurium pseudorufescens (Hampe) Maschke] Locations 3 \& 4; corticolous, semi-shaded, locally abundant, forming mats. Specimens examined:Ho 01-099, 01-100.

*Papillidiopsis aquaticum (Dix.) Boon-Chuan Ho \& B.C. Tan, comb. nov. [Basionym: Rhaphidostichum aquaticum Dix., J. Linn. Soc. Bot. 50: 127. 1935.] —Location 3; terricolous, river bank near the cascading waterfall, shaded, uncommon. Specimen examined: Tan 2001-19.

In Tan (1991), this aquatic species was treated as a phenotypic form of the terrestrial $P$. ramulina (Thwaites \& Mitt.) Buck \& B.C. Tan. The Endau Rompin collection has convinced us to accept it as a distinct species; hence, the necessity of the new combination proposal.

Papillidiopsis bruchii (Dozy \& Molk.) Buck \& B.C. Tan [syn. Rhaphidostichum bruchii (Doz. \& Molk.) Fleisch.] _Locations 3 \& 4; ramicolous, usually climbing among small branches and twigs, shaded, infrequent inside humid forest. Specimens examined: Tan 2001-09; Ho 01-035.

** Papillidiopsis complanata (Dix.) Buck \& B.C. Tan -Location 3; corticolous, semishaded, small populations. Specimens examined: Tan 2001-03, 2001-04; Ho 01082.

** Papillidiopsis malayana(Dix.) B.C. Tan [syn. Acroporium malayanum Dix.] - Location 1, uncommon. Specimen examined: $\mathrm{Ho}$ 01-295.

** Papillidiopsis ramulina (Thwaites \& Mitt.)
Buck \& B.C. Tan -Location 4; rupicolous, corticolous, semi-shaded, locally abundant. Specimens examined: Tan 2001-08; Ho 01-093.

* Pinnatella mucronata (Bosch \& Lac.) Fleisch. -Locations 1 \& 6; corticolous, deeply shaded, locally can be abundant. Specimens examined: Ho 01-098, 01-263.

**Pogonatum subtortile (C. Muell.) Jaeg. Location $4 \mathrm{a}$; terricolous, river bank, shaded, moderately abundant. Specimen examined: Tan 2001-30.

**Pseudotaxiphyllum pohliaecarpum (Sull. \& Lesq.) Iwat. -Locations 3 \& 6; lignicolous, shaded, locally abundant, forming purplish mats. Specimens examined: Ho 01-127, 01-271, 01-237.

Pyrrhobryum spiniforme (Hedw.) Mitt. Locations 3 \& 6; lignicolous, corticolous, sometimes rupicolous, near stream, shaded to deeply shaded, common. Specimens examined: Ho 01-036, 01-101, 01-106, 01-125, 01-291.

**Radulina hamata (Doz. \& Molk.) Buck \& B.C. Tan -Location 1; lignicolous, shaded, common. Specimens examined: Tan 2001-06; Ho 01-079.

***Rhaphidostichum bunodicarpum (C. Muell.) Fleisch. - Location 6; rupicolous, usually near stream, shaded, scattered populations. Specimens examined: Ho 01-234, 01-236, 01-286.

**Splachnobryum oorschoii (Lac.) C. Muell. Locations $2 \& 8$; terricolous or rupicolous, open, common in disturbed sites. Specimens examined: Ho 01-260, 01-261.

**Syrrhopodon albovaginatus Schwaegr. Location 1; lignicolous, deeply shaded, common, scattered populations. Specimen examined: Ho 01-055.

Syrrhopodon confertus Lac. - Locations 2, 3 \& 7; corticolous, semi-shaded to shaded, locally abundant. Specimens examined: Ho 01-056, 01-115, 01-250, 01-254.

Syrrhopodon croceus Mitt. - Locations 2, 4, 6 \& 7; usually lignicolous, sometimes corticolous, ramicolous or rupicolous, open to semi-shaded, very common, abundant. Specimens examined: Tan 2001-23, 2001-25, 2001-28, 2001-29; Ho 
01-044, 01-045, 01-048, 01-052, 01-246, 01-248.

Syrrhopodon loreus (Lac.) Reese - Locations 1, 3, $6 \&$ \&; corticolous, shaded, forming grass-like tuft. Specimens examined: Tan 2001-20, 2001-21; Ho 01-108, 01-129, 01-247, 01-249.

Syrrhopodon muelleri (Dozy \& Molk.) Lac. Locations 1, 3 \& 7; corticolous, ramicolous, shaded to deeply shaded, rather common. Specimens examined: $H o$ 01-047, 01-049, 01-113, 01-252.

Syrrhopodon prolifer Schwaegr. var. albidus (Thwaites \& Mitt.) Orban \& Reese [syn. S. albidus Thwait. \& Mitt.] —Location 3; rupicolous, semi-shaded, scattered populations. Specimens examined: Ho 01104.

Syrrhopodon spiculosus Hook. \& Grev. Locations 3 \& 4; ligicolous, corticolous, semi-shaded to shaded, common, locally abundant. Specimens examined: Tan 2001-13, 2004-26; Ho 01-053, 01-110, 01-117, 01-124.

Syrrhopodon tristichus Nees ex Schwaegr. Location 3; corticolous, shaded, locally common. Specimens examined: Ho 01054, 01-107, 01-111, 01-114, 01-130.

**Taxithelium instratum (Brid.) Broth. Locations 1 \& 6; corticolous, rupicolous, shaded to deeply shaded, common. Specimens examined: Ho 01-091, 01-279.

* Taxithelium isocladum (Bosch \& Lac.) Ren. \& Card. - Location 1; epiphyllous, shaded, not common. Specimen examined: Ho 01095.

** Taxithelium kerianum (Broth.) Broth. Locations 1, $6 \& 8$; epiphyllous and corticolous, shaded to deeply shaded, scattered populations. Specimens examined: Ho 01-102, 01-281, 01-282.

***Thuidium assimile (Mitt.) Jaeg. - Location 6; lignicolous, shaded, scattered populations, forming mats. Specimen examined: Ho 01-293.

This species differs from the widespread and common T. cymbifolium (Dozy \& Molk.) Dozy \& Molk. in having none to shortly piliferous stem leaves. The Endau Rompin plants do occasionally develop a few stem leaves with a hyaline hairpoint up to 15 cells long. In addition, the Endau Rompin plants are bipinnate and with young, eciliate perichaetial leaves. Admittedly, our identification of this species is based mainly on the observation of stem leaves showing very little hairpoint development (cf. Touw, 2001).

***Trichosteleum stigmosum Mitt. - Locations $3 \& 4$; usually lignicolous or rupicolous, less often terricolous, in open to shaded sites, common. Specimens examined: Tan 2001-07, 2001-14; Ho 01-080, 01-081, 01-083, 01-084, 01-121A.

**Trismegistia calderensis (Sull.) Broth. Location 3; lignicolous, semi-shaded, scattered populations. Specimen examined: Ho 01-087.

Trismegistia rigida (Mitt.) Broth. [syn. T. lancifolia (Harv.) Broth.] —Locations 6 \& 8; rupicolous, corticolous, sometimes ramicolous, near stream, semi-shaded to shaded, very common in primary rainforest. Specimens examined: Ho 01243, 01-244, 01-288.

Vesicularia dubyana (C. Muell.) Broth. Locations 2, 5 \& 6; corticolous, rupicolous, near stream, shaded, common. Specimens examined: Ho 01-272, 01-273, 01-237.

Appendix 2. List of mosses reported by Mohamed and Mohamad (1987) but not collected in this study.

Aerobryopsis wallichii (Brid.) Fleisch.

Calymperes dozyanum Mitt. [name misapplied to C. boulayi Besch. fide L.T. Ellis, pers. comm., 2002]

Calymperes palisotii Schwaegr. [probably $C$. moluccense Schwaegr. fide L.T. Ellis, pers. comm., 2002]

Calymperes schmidtii Broth. [the specimen was almost certainly C. subintegrum Broth. fide L.T. Ellis, pers. comm., 2002]

Calymperes tenerum C. Muell.

Campylopus serratus Lac.

Chaetomitrium beccarii Dix.

Chaetomitrium borneense Mitt. [syn. C. perakense Broth. ex Dix.] 
Ectropothecium monumentorum (Duby) Jaeg.

Ephemeropsis tjibodensis Goeb.

Fissidens ceylonensis Dozy \& Molk.

Fissidens hollianus Dozy \& Molk.

Fissidens papillosus Lac.

Himantocladium plumula (Nees) Fleisch.

Hypnodendron spininervium (C. Muell.) Jaeg. Isopterygium minutirameum (C. Muell.) Jaeg.

Leucobryum aduncum var. scalare (C. Muell. ex

Fleisch.) A. Eddy [syn. $L$.

microleucophanoides Dix. ex Johnson]

Leucobryum sumatranum Broth. ex Fleisch. [syn. L. pulchrum Broth.]

Leucoloma molle (C. Muell.) Mitt.

Mastopoma sp.

Mitthyridium subluteum (C. Muell.) Nowak

Mitthyridium wallisii (C. Muell.) Robins.

Pyrrhobryum latifolium (Bosch \& Lac.) Mitt. [syn. Pyrrhobryum longiflorum Mitt.]

Pogonatum piliferum (Dozy \& Molk.) Touw [syn. Racelopus pilifer Dozy \& Molk.]

Radulina elegantissima (Fleisch.) Buck \& B.C. Tan [syn. Trichosteleum elegantissimum Fleisch.]

Schistomitrium apiculatum (Dozy \& Molk.) Dozy \& Molk.

Sematophyllum microcladioides Broth.

Syrrhopodon involutus Schwaegr.

Syrrhopodon trachyphyllus Mont.

Thuidium pristocalyx (C. Muell.) Jaeg. var. samoanum (Mitt.) Touw [syn. T. glaucinoides Broth.]

Trichosteleum boschii (Dozy \& Molk.) Jaeg.

Trichosteleum complanatulum Bartr. 